\title{
KEPEMIMPINAN DALAM SUPERVISI PENDIDIKAN DI MADRASAH
}

\author{
BAHARUDDIN, LISA NURSITA \\ Universitas Islam Negeri Alauddin Makassar \\ Email: bahar.baharuddin@uin-alauddin.ac.id, lisa.nursita@uin-alauddin.ac.id \\ (Article History) \\ Received November 01, 2020; Revised November 07, 2020; Accepted November 09, 2020
}

\begin{abstract}
:
We try to explore the topic of the problem, namely leadership in supervision in madrasahs through the approach of several aspects and scientific points of view from several experts which are then summarized to find a common thread from each of the aspects found. We found that leadership is a technique or authority that is able to move other people both individually and in groups to carry out activities in achieving organizational goals. In madrasah institutions, educational supervision leadership is needed in order to improve the quality of learning. The duties of education supervisors include helping schools and the government to produce quality graduates, helping teachers develop their profession, helping schools work with parents or the community. Educational supervision leadership acts as a driving force and serves as a central force in improving the quality of learning in madrasah
\end{abstract}

Keywords: Leadership, Educational Supervision, Education Institutional

\section{PENDAHULUAN}

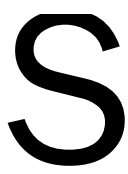

ebagai makhluk sosial, manusia sejatinya selalu berinteraksi dengan lingkungan sekitar dan hidup berkelompok. Hal ini tidaklah mudah karena

dibutuhkan sinkronisasi keharmonisan dalam kehidupan, serta menciptakan hubungan antar individu yang saling menghargai dan menghormati. Mengelola diri, kelompok/organisasi, dan lingkungan menjadi kehidupan yang harmonis merupakan tugas manusia yang memiliki jiwa pemimpin.

Pemimpin yang baik merupakan seseorang yang memiliki gaya kepemimpinan yang dapat mempengaruhi ataupun memotivator sumber daya manusia yang ada. Individu baik dalam lingkup organisasi maupun di luar, dapat digerakkan dan diarahkan untuk mengerjakan pekerjaannya demi mencapai tujuan organisasi yang telah ditetapkan, melalui salah satu fungsi manajemen yaitu kepemimpinan.

Dalam dunia pendidikan ada yang disebut supervisi pendidikan atau yang lebih dikenal dengan pengawasan pendidikan dan hal ini berkonsep dasar yang saling berkaitan. Pendidikan tidak sama dengan mengajar, pendidikan adalah suatu proses pendewasaan yang dilakukan oleh tenaga pendidik kepada siswa dengan memberikan stimulus positif yang mencakup pengetahuan, sikap dan keterampilan. 
Sedangkan pengajaran hanya berkaitan dengan menambah pengetahuan saja artinya pengajaran adalah suatu proses untuk mentransfer ilmu pengetahuan tanpa membentuk sikap dan keterampilan siswa. Dengan jelasnya konsep dasar ini, maka dapat disimpulkan bahwa pendidikan ini sangatlah penting, sehingga dibutuhkan supervisor untuk mengawasi pendidikan. Supervisor disini adalah Kepala sekolah dan pengawas lain yang berada dalam lingkup pendidikan, sehingga kualitas pengajaran dan pendidikan dapat ditingkatkan.

Tidak hanya pengawas yang berkewajiban melakukan supervisi pada lingkup madrasah atau sekolah, men-supervisi juga dilakukan oleh kepala sekolah. Kepala sekolah terdiri oleh dua kata, yaitu kepala dan sekolah. Dalam lingkup suatu organisasi atau pun lembaga pendidikan dimana terdapat peserta didik didalamnya, pimpinan tertinggi adalah kepala sekolah. Mengutip pernyataan Priansa (2014, h. 49) bahwa "Kepala sekolah dapat didefisinikan sebagai tenaga fungsional guru yang diberi tugas untuk memimpin sekolah tempat diselenggarakan proses belajar mengajar, atau tempat dimana terjadinya interaksi antara guru yang memberi pelajaran dan peserta didik yang menerima pelajaran". Berdasarkan pernyataan tersebut, maka jelas bahwa kepala sekolah diberi tugas dan wewenang untuk memimpin sekolah yang mana menjadi tanggung jawab kepala sekolah untuk mencapai tujuan sekolah dengan optimal, salah satunya adalah menjamin proses belajar-mengajar terselenggara dengan baik.

Kepala sekolah yang bertugas sebagai supervisor, harus pandai menemukan dan menentukan indikator-indikator apa saja yang penting dipenuhi oleh sekolah agar kualitas sekolah meningkat dan tujuan pendidikan di sekolah dapat semaksimal mungkin tercapai. Hal ini karena pendidikan merupakan pilar utama dalam kemajuan suatu bangsa. Sumber daya manusia yang memiliki kualitas pendidikan yang baik merupakan aset negara. Istibsjaroh Istibsjaroh dan Agustina (2019, h. 2) mengatakan bahwa "Pendidikan merupakan salah satu hal yang penting dari pembangunan bangsa Indonesia, maka pendidikan mendapat perhatian yang khusus. Dalam Undang-Undang RI No. 20 Tahun 2003 Tentang Sistem Pendidikan Nasional Tahun 2003 Pasal 3 ditegaskan tentang tujuan pendidikan nasional sebagai berikut:

"Pendidikan Nasional berfungsi mengembangkan kemampuan dan membentuk watak serta peradaban bangsa yang bermartabat dalam rangka mencerdaskan kehidupan bangsa, bertujuan untuk berkembangnya potensi peserta didik agar menjadi manusia yang beriman dan bertaqwa kepada Tuhan Yang Maha Esa, berakhlak mulia, sehat, berilmu, cakap, kreatif, mandiri, dan menjadi warga negara yang demokratis serta bertanggung jawab."

Agar dapat menjaga kualitas pendidikan maka perlu untuk menjaga keprofesionalan guru yang dalam hal ini sebagai individu yang merupakan penentu keberhasilan pendidikan melalui tataran institusional dan eksperiensial, maka 
sangat diperlukannya pengawasan melalui kegiatan supervisi baik dalam segi administrasi maupun pengajaran.

Berdasarkan uraian tersebut tulisan ini mencoba menelaah tentang (1) pengertian kepemimpinan; (2) pengertian dan fungsi supervisi pendidikan; (3) bagaimana gaya kepemimpinan yang baik dalam supervisi pendidikan. Dengan demikian tujuan tulisan ini adalah (1) untuk mengetahui pengertian kepemimpinan; (2) untuk mengetahui pengertian dan fungsi supervisi pendidikan; (3) untuk mengetahui gaya kepemimpinan yang baik dalam supervisi pendidikan.

\section{Metode Penelitian}

Penulis mencoba mengeksplor topik permasalahan dengan menemukan benang merah dari beberapa definisi dan penjelasan oleh beberapa ahli melalui pendekatan dari beberapa aspek. Artikel ini adalah bunga rampai, yang mengumpulkan beberapa definisi dari karya tulis ilmiah baik buku maupun jurnal dari berbagai sudut pandang keilmuan. Masing-masing topik sub-bab yang kemudian akan dijelaskan akan diberikan benang merah dengan topik sub-bab lain yang dijelaskan kemudian. Terakhir, penulis akan menyimpulkan seluruh definisi tersebut melalui pendapat sendiri.

\section{PEMBAHASAN}

\section{Kepemimpinan}

Solikin, Fatchurahman dan Supardi (2017, h. 92) mengatakan

"Dalam kehidupan sehari-hari, baik di lingkungan keluarga, organisasi, perusahaan sampai dengan pemerintahan sering kita dengar sebutan pemimpin, kepemimpinan serta kekuasaan, ketiga kata tersebut memang memiliki hubungan yang berkaitan satu dengan lainnya. Para ahli memaknai konsep pemimpin sebagai seseorang dengan wewenang kepemimpinannya mengarahkan bawahannya untuk mengerjakan sebagian dari pekerjaannya dalam mencapai tujuan."

Secara etimologi, Pamuji, (1995, h. 5) mengatakan bahwa ‘pimpin' yang berarti bimbing atau tuntun merupakan kata dasar dari kepemimpinan. Kemudian melalui kata inilah lahir kata kerja 'memimpin' yang merupakan arti dari kata membimbing atau menuntun.

Secara terminologi beberapa ahli mengemukakan pendapatnya terkait definisi kepemimpinan. Kreither dan Kinicki yang dikutip Bukhori, (2003, h. 21) mengatakan bahwa kepemimpinan adalah upaya mempengaruhi anggota untuk mencapai tujuan organisasi secara sukarela.

Berikut ini merupakan definisi dari kepemimpinan berdasarkan para pakar yang dikutip dalam Moeheriono (2012), sebagai berikut: 
1. Kootz dan O'donnel (1984), “Kepemimpinan sebagai proses mempengaruhi sekelompok orang sehingga mau bekerja bersungguh-sungguh untuk meraih tujuan kelompoknya."

2. Georger R. Terry (1960), "Kepemimpinan adalah kegiatan mempengaruhi orang-orang untuk berusaha mencapai tujuan bersama."

3. Slamet (2002), "Kepemimpinan merupakan suatu kemampuan, proses, atau fungsi, pada umumnya untuk mempengaruhi orang-orang agar berbuat sesuatu dalam rangka mencapai tujuan tertentu."

4. Thoha (1983), "Kepemimpinan adalah aktivitas untuk mempengaruhi perilaku orang lain agar supaya mereka mau diarahkan untuk mencapai tujuan tertentu."

Penulis berpendapat bahwa kepemimpinan merupakan proses mempengaruhi, memotivator, menggerakkan orang baik perseorangan maupun organisasi yang bertujuan untuk mencapai sebuah tujuan tertentu. Jika disinkronkan dalam dunia pendidikan, individu yang menjadi seorang motivator, penggerak, dan yang mempengaruhi seorang tenaga pendidik adalah kepala sekolah yang menjadi pemimpin dalam lingkup sekolah.

\section{Supervisi Pendidikan}

Supervisi pendidikan tertuju pada perbaikan proses belajar mengajar. Proses ini jelas juga berkaitan dengan kegiatan lain, diantaranya upaya untuk meningkatkan pribadi dan kualitas guru, kemampuan bersosialisasi dengan masyarakat dan juga orang tua siswa, serta upaya untuk meningkatkan kesejahtraan masyarakat. Dalam lingkup pendidikan supervisi utamanya bermuara pada tujuan akhir yaitu menghasilkan Iulusan berkualitas dan memiliki kompetensi yang memenuhi bahkan melampaui Standar Kompetensi Lulusan (SKL) yang telah ditetapkan.

Supervisi secara etimologi berasal dari dua kata yaitu 'super' yang artinya istimewa atau luar biasa, dan 'visi' artinya kemampuan untuk melihat pada inti persoalan. Dengan pengertian itulah supervisi bisa dikatakan sebagai kegiatan yang dilakukan oleh orang yang luar biasa atau istimewa yang dalam hal ini Kepala sekolah atau Rektor yang memiliki kemampuan untuk melihat inti persoalan dan menciptakan suasana belajar mengajar yang lebih baik.

Dikutip dalam Purwanto (2010, h. 76):

"Supervisi adalah segala bantuan dari para pemimpin sekolah, yang tertuju kepada perkembangan kepemimpinan guru-guru dan personal sekolah lainnya didalam menciptakan tujuan-tujuan pendidikan. Supervisi berupa dorongan, bimbingan dan kesempatan pertumbuhan keahlian dan kecakapan guru-guru, seperti bimbingan dalam usaha dan pelaksanaan pembaharuan-pembaharuan pendidikan dan pengajaran, pemilihan alat-alat pelajaran serta metode-metode mengajar yang lebih baik, cara-cara penilaian yang sistematis terhadap fase seluruh proses pengajaran dan sebagainya." 
Supervisi pendidikan dikutip oleh Ametembun (2007, h. 3) yakni "Pembinaan kearah perbaikan situasi pendidikan atau peningkatan mutu pendidikan." Untuk melaksanakan sasaran supervisi yaitu peningkatan kinerja secara efektif, maka perlu adanya peningkatan kemampuan guru. Dilihat dari uraian sebelumnya dapat diketahui bahwa fungsi dari supervisi pendidikan itu sendiri antara lain: (1) membantu sekolah maupun pemerintah menghasilkan lulusan yang memiliki kompetensi sesuai dengan SKL yang telah ditetapkan, bahkan lebih; (2) membantu guru mengembangkan profesinya; (3) membantu agar sekolah dan orang tua atau masyarakat dapat terjalin kerja sama dengan baik.

Fungsi supervisi menurut Ametembun dalam Maryono (2017), yaitu pertama penelitian, yang mana fungsi ini berarti harus menemukan solusi dari setiap masalah yang ditemui. Kedua penilaian, fungsi ini dapat mengukur tingkat kemajuan yang diinginkan, serta sebesar apa yang sudah dicapai. Ketiga, perbaikan merupakan usaha untuk mendorong atau memotivasi guru agar ingin melakukan perbaikan dalam pelaksanaan tugasnya. Keempat pembinaan, fungsi ini digunakan untuk memecahkan masalah yang sedang dihadapi melalui pembinaan atau pelatihan kepada guru tentang alternatif baru dalam pelaksanaan proses belajar-mengajar.

Dengan demikian dapat disimpulkan bahwa supervisi berfungsi untuk bantuan dari para pemimpin sekolah, yang tertuju kepada perkembangan kepemimpinan guru-guru dan personal sekolah lainnya di dalam menciptakan tujuan-tujuan pendidikan.

\section{Gaya kepemimpinan dalam Supervisi Pendidikan}

Guru dapat mencapai kepuasan kerja dengan adanya peranan dari pemimpin ideal yang mampu menerapkan gaya kepemimpinan yang tepat bergantung pada kondisi dan masalah yang dihadapi. Banyak model gaya kepemimpinan yang diungkapkan oleh para ahli, diantaranya seperti yang dikemukakan oleh Blanchard dalam Solikin, Fatchurahman dan Supardi (2017, h. 9) yang mengatakan bahwa ada empat gaya dari sebuah kepemimpinan, yaitu: (1) Directing, gaya ini digunakan untuk menyelesaikan tugas yang sulit dan bawahan yang belum berpengalaman dan termotivasi dalam mengerjakan tugas tersebut. Pimpinan mengarahkan apa yang perlu dan harus dikerjakan; (2) Coaching, pemimpin yang menggunakan gaya ini berciri khas selalu memberikan arahan secara rinci, instruksi secara jelas, dan mengawasi pekerjaan bawahannya dari jarak dekat, sehingga gaya ini dikenal juga dengan gaya pemberitahu; (3) Supporting, dalam gaya ini pemimpin memberikan fasilitas dan juga bantuan kepada bawahan dalam pelaksanaan tugasnya; (4) Delegating, pemimpin dalam gaya ini cenderung mendelegasikan tanggung jawab dalam pengambilan keputusan dan pelaksanaannya.

Keempat gaya ini memiliki kelemahan dan kelebihan, bergantung pada lingkungan kerja yang dihadapi pemimpin dan bagaimana kesiapan bawahannya. Idealnya, setiap pemimpin akan mampu memilih gaya yang sesuai dengan kondisi 
dan situasi, serta kemampuan guru dan bawahan/stafnya. Tidak ada gaya kepemimpinan yang dapat dikatakan terbaik diantara kesemua gaya yang ada, karena model kepemimpinan yang bisa diterapkan sangat bergantung pada kondisi dan situasi, serta pengalaman pengikut dan tugas yang perlu dilaksanakan.

\section{PENUTUP/SIMPULAN}

Kepemimpinan dan supervisi merupakan dua hal yang tak terpisahkan, bahkan dapat dikatakan bahwa kepemimpinan tidak bisa ada tanpa supervisi. Supervisi sangat berperan dalam menentukan berhasil tidaknya suatu kepemimpinan. Kepemimpinan merupakan proses mempengaruhi, memotivator, menggerakkan orang baik perseorangan maupun organisasi yang bertujuan untuk mencapai sebuah tujuan tertentu. Jika disinkronkan dalam dunia pendidikan, individu yang menjadi seorang motivator, penggerak, dan yang mempengaruhi seorang tenaga pendidik adalah kepala sekolah yang menjadi pemimpin dalam lingkup sekolah. Seorang pemimpin yang sukses adalah pemimpin yang memiliki keahlian dalam menguasai supervisi yang efektif. Supervisi pendidikan bertujuan memberi bantuan dari para pemimpin sekolah, yang tertuju kepada perkembangan kepemimpinan guru-guru dan personal sekolah lainnya di dalam menciptakan tujuan-tujuan pendidikan. Penerapan gaya kepemimpinan di setiap sekolah atau madrasah yang ideal bergantung pada kondisi yang terjadi dalam sekolah atau madrasah. Pimpinan diharapkan dapat menerapkan gaya kepemimpinan yang ideal dan mampu menciptakan lingkungan yang kerja kondusif, sehingga bawahan dapat bekerja dengan produktif.

\section{DAFTAR PUSTAKA}

Ametembun, N. . (2007) Supervisi Pendidikan Disusun secara Berprogam. Bandung: Suri.

Bukhori, H. I. (2003) Kepemimpinan Mengefektifkan Organisasi. Yogyakarta: Gajah Mada Univesity Press.

Istibsjaroh Istibsjaroh and Agustina, P. (2019) 'Peran Kepala Sekolah dalam Supervisi Pendidikan Agama Islam pada Kegiatan Belajar Mengajar di SMA Negeri Bareng Jombang', Al-Idaroh Jurnal Studi Manajemen, 2(2), pp. 1-23. Available at: https://jurnal.stituwjombang.ac.id/index.php/alidaroh/article/view/50.

Maryono (2017) Dasar-dasar dan Teknik Menjadi Supervisor Pendidikan. Malang: Ar Ruzz Media.

Moeheriono (2012) Pengukuran Kinerja Berbasis Kompetensi. Jakarta: PT. Raja Grafindo Jakarta.

Pamuji (1995) Kepemimpinan Pemerintah di Indonesi. Jakarta: Bumi Aksara.

Priansa, D. J. (2014) Rismi Somad, Manajemen Supervisi dan Kepala Sekolah. Bandung: Alfabeta.

Purwanto, N. (2010) Administrasi Dan Supervisi Pendidikan. Bandung: Remaja 
Rosdakarya.

Solikin, A., Fatchurahman, M. and Supardi, S. (2017) 'Pemimpin yang Melayani dalam Membangun Bangsa yang Mandiri', Anterior Jurnal, 16(2), pp. 90-103. doi: 10.33084/anterior.v16i2.41.

Undang-Undang RI No. 20 Tahun 2003 Tentang Sistem Pendidikan Nasional (2003). Jakarta: Cemerlang. 